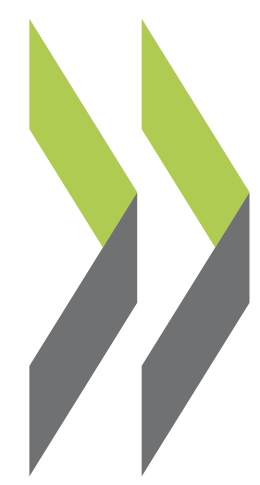

OECD Economics Department Working Papers No. 622

Reaping the Benefits of Stronger Competition in Network Industries in Germany 
Organisation de Coopération et de Développement Économiques

Organisation for Economic Co-operation and Development

ECONOMICS DEPARTMENT

English - Or. English

REAPING THE BENEFITS OF STRONGER COMPETITION IN NETWORK INDUSTRIES IN GERMANY

ECONOMICS DEPARTMENT WORKING PAPER No. 622

by

Nicola Brandt

All OECD Economics Department Working Papers are available on the OECD website at www.oecd.org/eco/working_papers. 


\section{ABSTRACT/RÉSUMÉ \\ Reaping the benefits of stronger competition in network industries in Germany}

The potential to strengthen productivity growth and enhance consumer welfare through more competition is large in the energy and railway sectors. Establishing stronger vertical separation between network access provision and potentially competitive services will be the main challenge for Germany going forward. In particular, it will be a crucial point in designing the envisaged privatisation of state stakes in the railway sector market incumbent Deutsche Bahn AG. In the energy sector, concentration in the wholesale market is another crucial issue that Germany will need to tackle, including by fostering market integration with neighbouring countries as well as market entry of newcomers. A more systematic approach to tendering unprofitable transport services will be key in the railway sector.

This Working Paper relates to the 2008 Economic Survey of Germany (www.oecd.org/eco/surveys/germany).

Keywords: Germany; Network Industries; Electricity and Gas Markets; Railways

JEL classification: L92; L94; L95

\section{Récolter les fruits de l'accroissement de la concurrence dans les industries de réseau}

L'accroissement de la concurrence présente dans les secteurs énergétique et ferroviaire un fort potentiel de croissance accrue de la productivité et du bien-être des consommateurs. Le principal défi que doit relever l'Allemagne dans un proche avenir est l'affirmation plus marquée d'une séparation verticale entre les services d'accès aux réseaux et les services potentiellement concurrentiels. Il sera en particulier crucial de préparer la privatisation envisagée par l'État des participations qu'il détient dans Deutsche Bahn AG, opérateur historique du secteur ferroviaire. Dans le secteur de l'énergie, la concentration du marché de gros est un autre point essentiel que l'Allemagne devra traiter, notamment en favorisant l'intégration du marché avec les pays voisins et l'entrée de nouveaux acteurs. Dans le rail, il sera essentiel d'opter pour le recours plus systématique à des appels d'offres en matière de services de transport non rentables.

Ce document de travail se rapporte à l'Étude économique de l'Allemagne 2008 (www.oecd.org/eco/etudes/allemagne).

Mots clés: Allemagne; industries de réseau; marché de l'électricité et du gaz; chemins de fer

Classification JEL: L92; L94; L95

\section{Copyright OECD 2008}

Application for permission to reproduce or translate all, or part of, this material should be made to: Head of Publications Service, OECD, 2 rue André-Pascal, 75775 Paris Cedex 16, France. 


\section{TABLE OF CONTENTS}

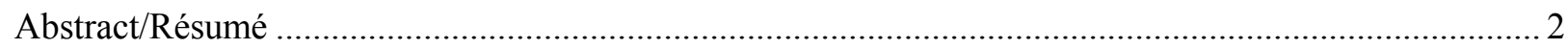

Reaping the benefits of stronger competition in network industries in Germany ........................................ 5

The root causes of weak competition should be addressed in the energy sector........................................ 5

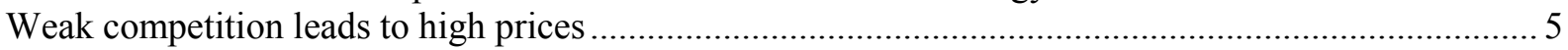

The government should take measures to reduce concentration in the wholesale market....................... 8

There is a need for stronger separation between network operation and competitive services ............... 10

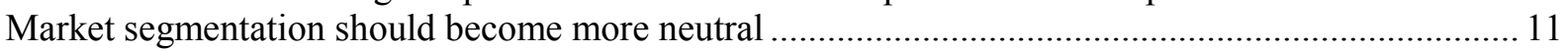

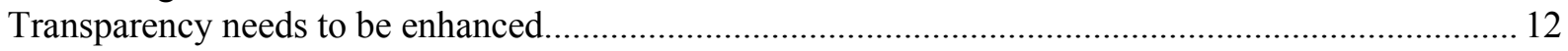

Independent sector regulation will need to be made fully effective ................................................ 13

Competition has had favourable effects in the railway sector but could be strengthened further............. 14

Competition has lowered prices and improved quality where it was allowed to take place................... 14

Political decisions on vertical separation will be crucial for the development of competition

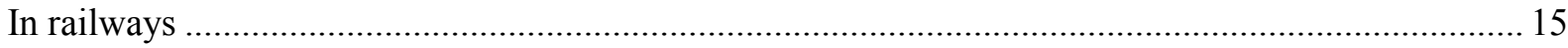

Regulatory oversight needs to be made more effective .................................................................... 18

Tendering subsidised services should become the norm ................................................................... 19

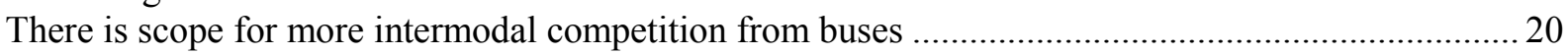

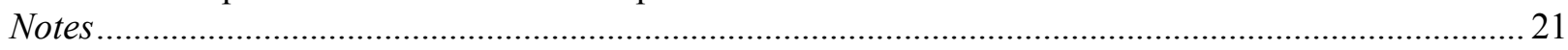

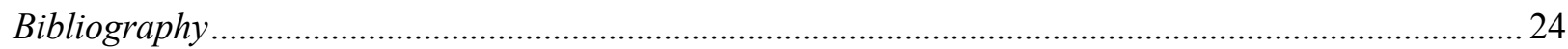

\section{Table}

1. Market shares in freight and railway passenger transport ............................................................. 14

\section{Figures}

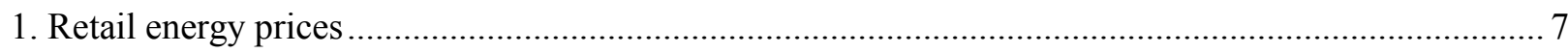

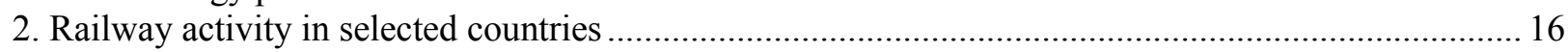

\section{Boxes}

1. Market concentration and vertical integration in the gas and electricity sectors.................................. 8

2. Recommendations to enhance competition in network industries ................................................... 20 
ECO/WKP(2008)30 


\title{
REAPING THE BENEFITS OF STRONGER COMPETITION IN NETWORK INDUSTRIES IN GERMANY
}

\author{
by Nicola Brandt ${ }^{1}$
}

The scope to boost productivity growth through more effective competition in the energy and railway sectors is large and this could have beneficial effects on overall productivity growth and potential, both directly and indirectly, as these sectors produce important intermediate inputs for the rest of the economy. There is also considerable scope to enhance consumer welfare through potentially favourable effects of stronger competition on prices and quality.

Competitive service provision in these industries hinges on free and fair access to networks prevalent, which are subject to large sunk investment costs and therefore natural monopoly characteristics. In the railway sector this also extends to other essential facilities, such as stations and traction energy and to some extent to the rolling stock (trains) and distribution. Competition policy therefore faces similar challenges in these sectors and experience in one of them may imply useful lessons for the others. Specifically, the government may need to keep in mind the difficulties it currently faces in trying to establish functioning competition in the energy sector when designing the envisaged privatisation of the state-owned incumbent in the railway sector.

\section{The root causes of weak competition should be addressed in the energy sector}

\section{Weak competition leads to high prices}

German households and industrial consumers have to cope with some of the highest gas and electricity prices in Europe (Figure 1) and much points to a lack of effective competition as the main reason for this. Unlike in other European countries, a liquid market for gas trading has not developed in Germany to this date. While liberalisation started relatively early with consumers having had the legal right to choose their suppliers ${ }^{1}$ since 1998 , little attention was given in the beginning to the benefits of a strong separation between potentially competitive services and network access provision or to the need for forceful regulatory interventions to ensure free and fair network access for all competitors. Concentration was already high before the onset of liberalisation, but it was allowed to increase thereafter (OECD, 2006). In particular, the experience with self-regulation, whereby market participants negotiated network access among themselves with lighter regulatory oversight, had not been encouraging. While the competitive framework is improving, thanks to the revised Energy Act that came into force in July 2005 and the establishment of a sector regulator, the Federal Network Agency (FNA), it takes time to show effects, and some of the decisions taken earlier in the liberalisation process are hard to reverse. Crucial points that will need to be addressed to improve competition include the following:

This paper is largely based on material from the OECD Economic Survey of Germany published in April 2008 under the authority of the Economic and Development Review Committee (EDRC). The author would like to thank Ulrik Stridbaek, Daniel Simmons, Stephen Perkins, Christoph Schoser, Val Koromzay, Andrew Dean, Andreas Wörgötter, David Carey and Felix Hüfner for valuable comments on earlier drafts. The paper has also benefited from discussion with the German authorities. Special thanks go to Margaret Morgan for technical assistance and to Josiane Gutierrez for technical preparation. 
- Concentration: Concentration is very high in the wholesale market in both the electricity and gas sectors and both market entry of newcomers and more competition from abroad will be needed to overcome this.

- Vertical integration: The dominant companies also own and operate the largest part of the transmission network, implying disincentives for them to provide network access under fair conditions for their competitors or to invest in capacity to allow for more independent market entry. To address this issue, the European Union requires its member countries to separate or unbundle network access provision from potentially competitive services in energy markets, but leaves considerable freedom as to how far unbundling has to go. Germany has chosen a weak form of compliance with European unbundling requirements. The legal right to nondiscriminatory access to the network for third parties is enforced via regulation. Incidentally, implementation is difficult and it takes time, while regulation will remain very demanding in this context.

- Market segmentation: Market areas in both the electricity and gas markets tend to be delineated along network property lines, creating further possibilities for large vertically integrated companies to discriminate against competitors. In the gas sector, the large number of market areas makes entry costly and bureaucratic for newcomers.

- Transparency: There is a lack of transparency about the availability of infrastructure. This creates an information asymmetry between independent companies and vertically integrated incumbents, making it difficult for new entrants to understand the market and challenge incumbents if they think they have been unfairly denied network access.

- Effective sector regulation: While FNA has entered the scene as an independent sector regulator in 2005, the legacy of self-regulation and negotiated network access practiced before is still present, so firmly establishing independent regulation remains a challenging task and remaining legal loopholes are not helpful in this respect.

One symptom of weak competition are small customer switching rates, $1.25 \%$ ( $7 \%$ including switching to a more favourable contract with the same supplier) in the gas sector and around $8 \%$ in the electricity market in terms of total final consumption (Bundesnetzagentur, 2007), considerably lower than in other European countries (see EC, 2005). However, this process has gained some speed lately owing to announced price increases and thanks to the regulator's efforts to facilitate switching procedures in both sectors.

While the government is working on addressing these issues progress takes time and meanwhile prices remain high. Recent price increases together with the industry's announcements of more to come have sparked vivid controversy in Germany, leading the government to consider how to strengthen the Federal Cartel Office's (FCO) powers to act against an abuse of market power in the energy sector and create visible effects in the short term. In particular, the amendment of the Gesetz gegen Wettbewerbsbeschränkungen (Act against Restraints on Competition) considers prices or conditions that are substantially less favourable than those of competitors or of companies on comparable markets to suffice as evidence for the FCO to act against an abuse of market power. Alternative evidence would be prices unduly exceeding costs. The burden of proof would be shifted to the industry. The law will expire by 2012 because it is considered as a short-term measure to bring immediate relief to customers, before broader measures to strengthen competition can take effect. 
Figure 1. Retail energy prices

Electricity price, euros/megawatt hour

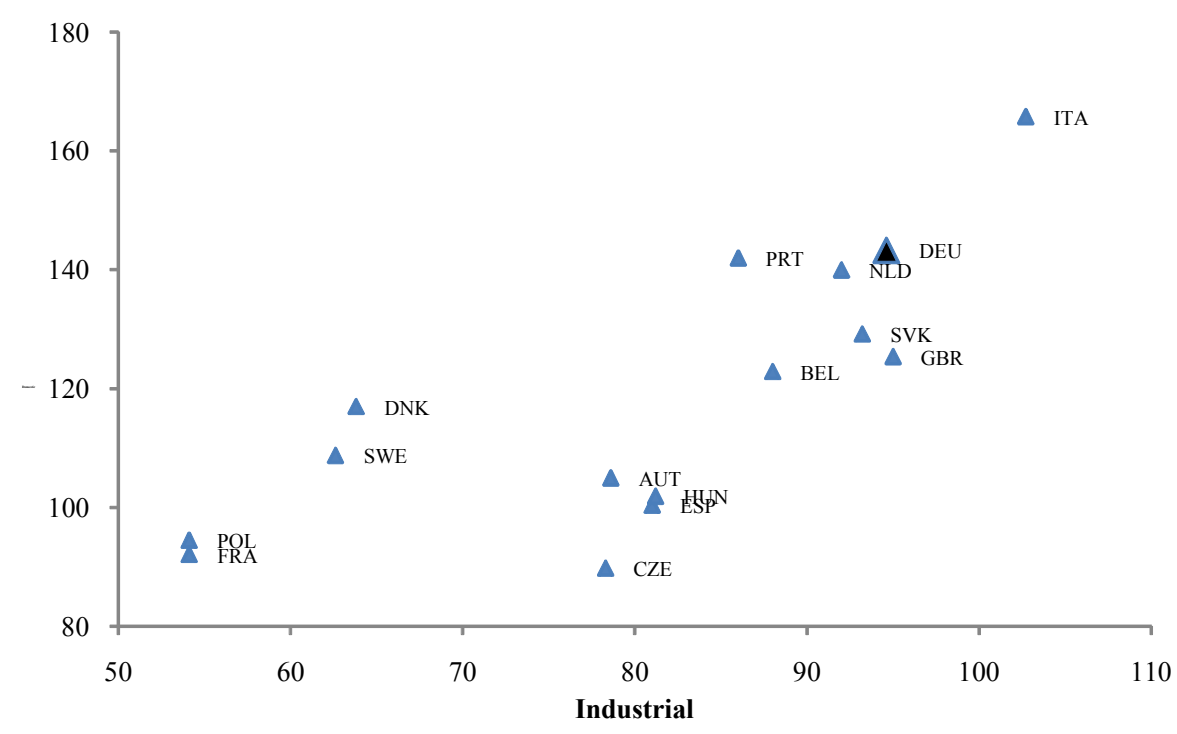

Natural gas price, euros/gigajoule

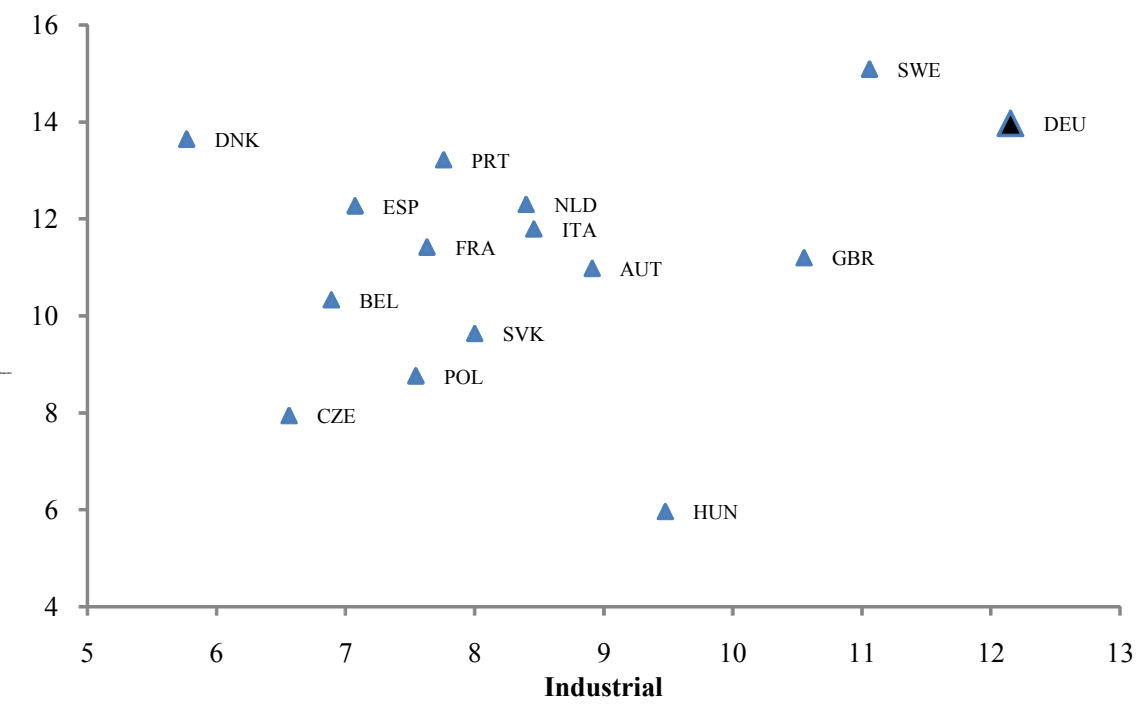

Note: All prices exclude all taxes and refer to $1^{\text {st }}$ January 2007.

Source: Eurostat.

While the aim of the law is to curb price setting power of large incumbents, there is a risk that the law could instead harm competition in a more fundamental sense and undermine its potential to bring down prices. By effectively requiring energy companies to match their competitors' prices, the law could stabilise collusive behaviour, since competitors would have to follow once a market incumbent lowers prices if the law is applied vigorously (see also Monopolkommission, 2007a). Thus, while the law may accelerate the diffusion of lower prices set by successful market entrants throughout the sector it could also lower the chances of successful market entry. It therefore risks acting as a disincentive to attempt market 
entry. ${ }^{2}$ The fact that the law will expire in a few years opens the possibility to address the underlying problem of German energy markets rather than to deal with the symptoms of high prices. In what follows, possibilities for the government to foster competition are discussed.

\section{The government should take measures to reduce concentration in the wholesale market}

The concentrated structure in electricity generation (Box 1) entails the risk of strategic behaviour by incumbent companies, such as tacit collusion, that could make market entry for newcomers difficult. In the electricity market, independent companies are finding it hard to trade electricity bilaterally across market areas covered by networks of different vertically integrated incumbents. This could indicate that these companies have effectively divided the market geographically (Monopolkommission, 2007b). Several studies have found evidence that the market-dominating companies in the electricity sector have exercised their market power by setting prices significantly above cost, including by holding back capacity (Müsgens, 2006; Lang and Schwarz, 2007; Hirschhausen et al., 2007a; London Economics, 2007). The FCO is currently investigating evidence for collusion between market dominant companies in the electricity sector. While it is not clear that it will be possible to find hard proof of such behaviour, the perception that tacit collusion takes place may well be a barrier to entry for newcomers. Indeed, independent companies report that they find it hard to judge the profitability of planned investments (EC, 2006).

\section{Box 1. Market concentration and vertical integration in the gas and electricity sectors}

Concentration had already been high before the onset of liberalisation, but it has increased further thereafter as companies were allowed to merge across all stages of the production chain, although the FCO gave its clearance for mergers only when it could not find evidence for a possible negative impact on competition. In the electricity market, the four largest producers and their associated trading sisters and affiliated companies now control around $90 \%$ of total electricity generation capacity (EC, 2006). In the gas market, a few big companies contract all gas imports, while also controlling national production. Since the merger of Ruhrgas and EON was allowed in 2002 by ministerial decree, overruling a decision by the FCO, Ruhrgas-EON has controlled $60 \%$ of the wholesale market. Moreover, the gas and electricity sectors are closely intertwined, with two of the big four electricity companies being major gas wholesale suppliers.

The largest part of the transmission network is owned and operated by the large vertically integrated companies, which also own significant stakes in retail companies and control other essential facilities. In the electricity sector, the country is divided into four large market areas, plus two smaller ones, each of which is covered by a transmission network owned and operated by one of the large four companies. As these companies have acquired shares in municipal utilities, they also control close to $50 \%$ of the retail market. The big players in the gas market own $80 \%$ of the storage capacity and a large part of the transmission system, together with a number of regional transmission companies. Most of the incumbent companies have acquired shares in municipal utilities which, in addition, have tended to be tied to wholesale gas suppliers through long-term supply contracts with prices determined by those of delivered oils. Ruhrgas-EON alone controls $30 \%$ of the retail market.

One measure to address the issue of high concentration would be to increase the relevant market and enhance competition from abroad by extending cross-border interconnection capacity and improving management of existing capacity. In the electricity sector, cross-border interconnections are owned and operated by the big four electricity generation companies and the associated capacity is frequently congested. Capacity at congested borders is auctioned and under EU rules revenues can be used for investments in interconnection capacities, but also for investments in other parts of the network or reductions of network tariffs. German grid operators that manage interconnection capacity have used only $€ 20-30$ million for investments in interconnection capacity out of $€ 400-500$ million revenues from auctioned capacity earned during the period 2001-05 (EC, 2007). To speed up market integration with neighbouring countries, the government should require companies to use revenues from cross-border 
auctions exclusively for investments in interconnection capacity, as long as congestion remains a problem (IEA, 2007). Vertically integrated, market dominant companies have weak incentives to invest in network extension, even if there are physical bottlenecks. It may be worth considering giving the regulator the power to order investment in capacity if necessary, as long as the market structure remains as concentrated as it currently is (Monopolkommission, 2007b). The government and its regulator should continue to work together with companies on improving capacity management in line with existing regulations.

Similarly, competition and market entry in the gas market could likely be enhanced through a combination of cross-border interconnection capacity extension and a more rigorous enforcement of existing capacity release and management rules, as new entrants are finding it difficult to secure transit capacity on key routes or entry capacity into the German market. The interconnection capacities in the gas grid are almost completely booked for the coming years. The domestic network is subject to contractual congestion. Four of the five big transmission network operators, who operate around $70 \%$ of the total capacity, report contractual congestion in their transmission network and three quarters of the booked capacity are subject to contract terms of more than one year. In contrast, physical capacity constraints seem to be less important (Bundesnetzagentur, 2007). While contractual congestion entails a legal requirement for transmission system operators to auction the remaining capacity, only one of the major transmission system operators held such an auction in 2006, a decline from the year before. Measures to prevent capacity hoarding, such as use-it-or-lose-it-provisions that require a release to the secondary market of booked capacity that is not fully used, do not seem to have been applied and capacity trading on the secondary market remains negligible (Bundesnetzagentur, 2007). The regulator is working on improvements of capacity allocation and management. The regulator should be vigilant in enforcing existing capacity release and auction requirements to enhance competition in the future.

In addition, making it easier for newcomers to enter the market as well as diversifying supply sources could help alleviate the problem of high concentration in both the electricity and gas markets. This could be done by speeding up processes to obtain an authorisation to operate power plants or Liquefied Natural Gas (LNG) terminals, which currently play no role, for gas imports into Germany, and by ensuring fair access and fast connection to the transmission network, especially if new capacity goes to newcomers. In the electricity market, the government passed a decree in June 2007 laying out how to implement the legal requirement for fast and fair network access and grid connection for new power plants with privileged network access. ${ }^{3}$ The new decree is a welcome step, as there had previously been reports of newcomers being denied grid connection and existing capacity rights of old power plants seemed to have enjoyed priority vis-à-vis the demands of new power plants (grandfathering rights). However, going forward the government might consider going a step further by providing privileged network connection solely to newcomers as a way to deal with the problem of strong concentration.

Given that wholesalers trade only negligible quantities of their gas on existing gas exchanges ("hubs"), gas release programmes can be a useful means to increase market liquidity and create additional entry opportunities. The German experience has shown, however, that the design is crucial. The controversial merger of EON and Ruhrgas was subject to the requirement that the merged company would release certain quantities of gas in six annual auctions until 2008. The first auctions were not successful, because bidders were unable to secure transport capacity on EON-Ruhrgas's network. After an intervention of the regulator the 2006 auctions were constructed with transport capacity provided and demand was significantly higher than in previous years. The government should consider requiring market dominating companies to release further gas quantities along with provision of the required transport capacity as this would help increase market liquidity. While such interventions would most likely restrict property rights it does not seem to be excluded that they are in line with the German constitution. See Engel (2007) on the issue of restrictions of property rights to complete efficient competition law. 


\section{There is a need for stronger separation between network operation and competitive services}

Due to the transmission networks' natural monopoly features, allowing them to be owned and operated by companies that are also active in competitive parts of the industry, as in Germany, can lead to market foreclosure. Transmission network operators belonging to a vertically integrated company have ample incentives and opportunities to make network access expensive and difficult for competitors of its affiliate companies, e.g. by withholding information or capacity as well as through cross-subsidies. This could be addressed through more forceful regulation, but operation of the network and investments are so complex that even extensive regulatory intervention cannot strip network owners and operators of all their discretionary powers and tying their hands too forcefully may even put electricity system security in jeopardy. Therefore, full ownership unbundling, that is the creation of a separate network owner and operator with no ties to the incumbent, is in principle the most straightforward way to tackle this problem and should not be excluded as an option. It makes the regulator's task a lot easier by abolishing the network operators' incentive to discriminate against independent companies seeking network access. Experience in countries that have chosen this route, such as the UK and Nordic countries, seems to suggest that full ownership unbundling can be very helpful in establishing effectively competitive markets with low prices and secure supply. ${ }^{4}$

Germany has implemented EU unbundling requirements by choosing the weakest form of the required separation between network access provision and potentially competitive services. The EU requires the network operator to be unbundled legally, operationally and in terms of the exchange of market-sensitive information (informational unbundling or "Chinese walls"), but it can still belong to the same holding company. While legal and accounting unbundling are largely implemented now, although progress was slow particularly in the gas sector, this is not the case for operational and informational unbundling. A number of unbundled transmission system operators work with very few own staff, while strategic functions and a large part of operative services remain with the holding company. More than $70 \%$ of the companies report sharing some staff in this way (Bundesnetzagentur, 2007). This raises questions as to whether operational and informational unbundling are effective. While the law does not allow managerial staff of the network operator to hold positions in other parts of the holding company, non-managerial staff can be shared. This gives the holding company ample possibilities to influence the network operator and obtain information that is not available to others. The government should review whether sharing staff should be allowed, while existing unbundling requirements should be enforced swiftly and vigorously. Meanwhile $10 \%$ of the network operators with more than 100000 clients still have not implemented the requirements concerning managerial separation. Overall, there are only a few network operators that are geographically separated from other affiliate companies or aim at developing their own trademark, e.g. with a separate internet domain. In addition, two thirds of the legally unbundled companies still share integrated electronic information systems containing information on both the network and distribution (Bundesnetzagentur, 2007).

The development in Germany seems to show that enforcing operational and informational unbundling of companies belonging to the same holding is a challenge for the regulator, to say the least. The government should consider whether it does not want to go for a stronger form of separation to improve the competitive framework faster and make regulatory oversight easier. Ownership unbundling is a good way to remove incentives for the network operator to discriminate against independent companies. Admittedly, this could raise thorny legal issues in Germany, as companies in the energy sector are private and the government argues that requiring them to sell network assets would amount to expropriation. ${ }^{5}$ However, from an economic perspective successful unbundling will reduce the value of the network to the price that can be obtained by selling it to an independent company on the market, while it is worth more for a vertically integrated company as long as it can use its power over network assets to discriminate against competitors. In this sense, successful unbundling of whichever kind will lead to some sort of expropriation, namely of existing rents. Regarding the weaker form of unbundling currently pursued in Germany, it is 
doubtful whether it is possible to enforce Chinese walls between companies that belong to the same holding and thus have close personal ties as well as a shared economic interest in maximising their aggregate profits. While ongoing efforts to optimise weaker forms of unbundling are certainly welcome the verdict is still out on whether this could deliver the same positive effects as full ownership unbundling. Given that the latter option would make it far easier to create a level playing field for all companies, Germany should carefully weigh the practical difficulties of unbundling vertically integrated companies without ownership separation against the legal difficulties of full ownership unbundling. An intermediate solution that is worth considering would be the establishment of an independent transmission system operator with no personal or ownership ties to the incumbent, which operates the network independently, but without actual ownership of network assets themselves. This has worked well in a number of countries, including the United States and Australia.

In the gas market, vertical foreclosure preventing a liquid gas market from developing has also been related to long-term contracts which have, however, been recently overruled by the FCO. These contracts have tied downstream companies to single suppliers over long periods, sometimes up to 20 years. The FCO has overruled long-term contracts that exceed 2 years if the consumer is forced to cover $80 \%$ or more of its demand from one consumer as well as contracts with a duration exceeding 4 years that require the consumer to cover $50 \%$ or more of its demand by one supplier. The implementation of shorter contracts or contracts which cover a smaller part of the downstream companies' needs will brighten prospects for more effective competition in the gas market; but other issues will need to be resolved as well, including full establishment of a functional network access model.

\section{Market segmentation should become more neutral}

Market areas in both the electricity and gas markets tend to be delineated along network property lines. ${ }^{6}$ Given that most of the network owners belong to large vertically integrated companies, this involves additional possibilities for them to discriminate against competitors. When providing balancing services required to ensure that supply matches demand in each market area, ${ }^{7}$ or balancing zone, network operators belonging to vertically integrated companies can favour their affiliates as suppliers. In addition, they can discriminate against independent network users by generating overly high prices. While prices for balancing services are effectively transfer prices for their affiliates with no real impact on the corporation's profits, they are real costs for independent companies. In Germany, prices for balancing energy tend to be significantly higher than in other European countries, and spreads between buy and sell prices are large, indicating that the market is not operating efficiently. In an efficient market, buy and sell prices would converge to the spot price (for details see IEA, 2007).

The problem is particularly pressing in the gas market, as it is fragmented into more than 8 market areas compared to only one in the UK, a gas market of a similar size. Fragmentation is costly and bureaucratic for network users, because the risk of being in imbalance and facing onerous penalty charges ${ }^{8}$ collected by the transmission system operator is higher in smaller market areas where portfolios are smaller. In Germany, penalty charges tend to be significantly higher than in other European countries, which may well be related to a lack of independence of the system operators (EC, 2007).

In addition, with the industry-drafted market access model that is now in place - the entry-exit model - traders transporting gas across several market areas need to negotiate in parallel to reserve capacity at each border point when gas leaves or enters a market area. ${ }^{9}$ This is not only cumbersome, but it also requires a functioning capacity allocation mechanism, and there are doubts whether this requirement is fully met in Germany. As discussed above there is a lot of contractual congestion, even if physical capacity is available, and mechanisms to release unused capacity do not seem to work in many cases. Transmission system operators have also been reported to grant grandfathering rights to capacity to their affiliated companies and they often sign contracts with their affiliates in non-transparent ways (EC, 2007). 
Moreover, traders that would want to transport gas through several market areas will face a host of different network access charges (Monopolkommission, 2007b). This makes market entry bureaucratic and expensive and sometimes it is outright impossible under economically meaningful conditions.

Merging market areas further would make market entry far easier for independent companies and thus improve competition. The market access model and the number of market areas that have emerged now had been negotiated via voluntary cooperation agreements moderated by the regulator, which turned out to be a lengthy process. Initially, the agreement included a network access model which the regulator later found to be incompatible with legal requirements for free and fair network access. ${ }^{10}$ The regulator is currently looking into whether a further integration of market areas would comply with the legal criterion of technical feasibility. Given the market set-up in other countries of similar size, one area for each of the two different qualities of gas that are transported through German pipelines might well turn out to be sufficient. Indeed, it is possible to convert gas into different qualities, so that it would also be technically feasible to have only one market area. Whether this would be economically sensible needs to be investigated, however. If market area integration is found to be desirable it should be possible for the regulator to order this, rather than only relying on voluntary agreements, so as to ensure that consumers can reap the benefits of enhanced competition as quickly as in other countries.

In both the gas and the electricity sectors integration of market areas across networks of different owners might also contribute to the independence of transmission system and balancing operations and thereby network clients' confidence in fair market operation. Indeed it could lead to the establishment of independent system operators, as different network owners would need to operate market areas together. This could thus solve many of the problems that hinder the establishment of competitive markets in Germany. However, as long as electricity generation remains as concentrated as it is now, a competitive market for balancing energy is unlikely to develop. Germany may need to consider price controls in the balancing energy market until decisive measures, such as enhanced possibilities for newcomers to enter the market and an extension of cross-border interconnection capacity, have reduced concentration in electricity generation.

Effective competition not only requires non-discriminatory third-party access to gas pipelines but it will also be important to ensure free and fair access to storage capacity to ensure functioning competition in gas trading. Gas storage is a vital source of flexibility for shippers given the difficulties in predicting demand in any network. In Germany, control over existing storage capacity is highly concentrated (Box 1) and access to it is very difficult for independent companies (Bundesnetzagentur, 2007). 80\% of the capacity has been booked for more than 5 years, in some cases for 15 years (EC, 2007). ${ }^{11}$ The government should consider making it mandatory to auction storage capacity on an annual basis to all market players, rather than allowing companies to book the large majority of capacity through long-term contracts (IEA, 2007).

\section{Transparency needs to be enhanced}

Transparency also needs to be enhanced in both the electricity and the gas markets. In fully competitive markets, independent network operators have an incentive to advertise their services and provide information about available capacity, conditions and prices of network access and other elements that are crucial for market participants' efficient decision making. In Germany, vertically integrated network operators have incentives to withhold information instead, but some information requirements are imposed on them by law. However, a number of companies still does not comply fully with their legal reporting requirements, including regarding the availability of transport and storage capacity or conditions and charges for network access (Bundesnetzagentur, 2007). 
While the European Energy Exchange (EEX) in Leipzig has recently started to post data on installed and available capacity in real time, as well as ex post net production data, the reporting by generation companies is voluntary and at present the data cannot be considered complete or reliable. In such an environment it would even be possible for generation companies to use selective data publication for manipulation (IEA, 2007).

Compliance with legal publication requirements of data on physical and contracted capacity in the gas market has improved in 2006, but it remains incomplete and often difficult to find (Bundesnetzagentur, 2007). In contrast, total capacity and flow data is available on a daily basis on a public website in France and in the United Kingdom nominations and capacity are reported in advance. BEB, the only network in Germany that is not owned by a majority shareholder publishes such flow information, as well. With reliable flow information market participants would be better able to gather their own evidence on whether they have been unfairly denied access to the grid. Germany should ensure that existing minimum transparency standards cover all the necessary information and require verification of the data by an independent third party, while ensuring enforcement (for details see IEA, 2007).

\section{Independent sector regulation will need to be made fully effective}

Until the FNA was established in 2005, determination of network access conditions was largely left to negotiated self-regulation. This model has not succeeded in providing for free and fair third-party access to the network. The negotiated network access model that has been in place in the gas market since the first EU gas directive seems to have forestalled market entry until now and network access charges in both the electricity and gas sectors exceed the European average to a considerable degree (OECD, 2006; EC, 2005).

The regulator has completed its first round of network access charge regulation, which has led to sizeable reductions (Bundesnetzagentur, 2007). However, the process has been frequently delayed, including as a result of the failure of companies to provide meaningful information in a number of cases. Due to staff limitations the regulator was not able to review all cost parameters, but had to concentrate on some (Monopolkommission, 2007b).

The move towards incentive-regulation in the gas and electricity markets envisaged for 2009, whereby the costs of the most efficient company in the sector would serve as a benchmark instead of the actual costs of each company as today, can be expected to lower access charges further, while preserving incentives for operators to reduce their costs. However, it will be important to ensure that the accepted benchmark costs are not too high and that they truly reflect the costs of the most efficient provider (for details, see OECD, 2006). On the other hand, incentive regulation also has to take quality into account, in particular incentives for sufficient investment in networks. For incentive regulation to be introduced as fast as possible, it will be important to swiftly complete the second round review of network access charges based on costs but to do so with care, as this will be the benchmark for the ensuing incentive regulation.

In some cases, escape clauses in the law are delaying effective regulation. In the gas sector, key longdistance pipelines, which are crucial for entry into the German market, are not subject to ex-ante price regulation, as their owners have invoked an escape clause that would exempt them if they can show that there is functioning competition among network providers. While it its true that it would be desirable to forego regulation if competition were functioning, this is very unlikely to be the case for several reasons: There are only two parallel gas pipelines, while network infrastructure in this market is subject to large sunk costs, economies of scale in network operation and expansion and network effects of pipeline systems. Even in the United States, where a large number of operators meet high demand and some pipelines run in parallel, there is no effective or potential competition between network operators, which is why network access charges remain regulated (Hirschhausen et al., 2007b). Yet, because of the escape clause in the law the regulator has to review the claim that there is functioning competition each time the 
clause is invoked. Meanwhile, unregulated network access charges are likely to be too high and discriminatory. Germany should review escape clauses in the law to ensure that effective competition can emerge faster.

While large network operators (more than 100.000 connected customers to the grid or crossing the borders of two Länder) are regulated by the FNA, Länder regulators are in charge of smaller operators whose network is within the borders of one Land and this fragmentation of the regulatory framework may have to be reviewed. It has already become apparent that regulation practices differ between the different regulators (for examples see Monopolkommission, 2007b). While a number of Länder have transferred their regulatory powers to the FNA and a committee (Länderauschuss) is in charge of harmonising regulation, this may not be enough. Centralisation of regulation to ensure that the same rules apply to all players seems to be a first best option. Should the government consider this not to be feasible for constitutional reasons, at a minimum, co-ordination and consultation among regulators should be stepped up

\section{Competition has had favourable effects in the railway sector but could be strengthened further}

\section{Competition has lowered prices and improved quality where it was allowed to take place}

The difficulties in establishing a competitive market in the energy sector with large vertically integrated and privately owned companies dominating the market implies important lessons for the railway sector. Germany is currently envisaging privatising Deutsche Bahn $A G$ (DB AG), the state-owned market incumbent, and the decision on whether DB AG should continue to own and operate the tracks thereafter may well be crucial in determining the chances for competition to develop further in this sector. In this respect, it will be important to keep in mind the difficulties of achieving sufficient separation between network access provision and the potentially competitive parts of the industry once a company has been privatised along with its network assets.

While progress has been made, the liberalisation of the railway sector has not reached all of its goals. When Germany opened the railway network to competition in 1994 and transformed Deutsche Bahn and Reichsbahn into a private corporation, DB AG, reform goals included providing relief to public finances and directing more transport to railways. Competition was seen as a vehicle to achieve these goals. Yet, to date DB AG retains its dominant market position. While competitors have been able to increase their market share significantly in freight transport in recent years, it remains well below $10 \%$ in passenger transport (see Table 1) and in longer distance passenger transport services competition is virtually nonexistent.

Table 1. Market shares in freight and railway passenger transport Ton kilometres and person kilometres respectively

\begin{tabular}{ccc|cc}
\hline & \multicolumn{2}{c|}{ Passenger transport } & \multicolumn{2}{c}{ Freight transport } \\
\cline { 2 - 5 } 2001 & DBAG & Competitors & DBAG & Competitors \\
\cline { 2 - 5 } 2002 & 96.8 & 3.2 & 97.1 & 2.9 \\
2003 & 96.1 & 3.9 & 95.2 & 4.8 \\
2004 & 95.7 & 4.3 & 93.1 & 6.9 \\
2005 & 94.4 & 5.6 & 90.4 & 9.6 \\
2006 & 94.3 & 5.7 & 85.9 & 14.1 \\
\hline
\end{tabular}

Source: $D B A G$ Wettbewerbsbericht, various issues. 
The goal to shift more transport to railways has not been achieved in the passenger sector, in particular on long-distance lines, although competition in the freight sector does seem to have had a small, but positive and rising, effect. The volume of rail freight services provided and their market share in overall freight including other means of transport, the modal split, has developed favourably since more competitors have entered the market beginning around the turn of the century (Figure 2). In passenger transport, the position of railways in the modal split has been stagnant overall since the rail reform was launched. It should be noted that the development of rail transport service performance has been stronger both absolutely and in terms of market share in Sweden and the United Kingdom, where competition is livelier and the separation of the network operator from transport service enterprises is stronger (see also $\mathrm{KCW}$ et al., 2005). However, passenger transport services in particular have also developed more strongly in some countries with little or no competition in this market segment, such as France and Switzerland. While this suggests that competition is not a necessary prerequisite to boost the railway sector, Germany has in principle chosen competition as a vehicle to achieve its transport policy goals by opening railways to independent transport service providers. The example of Sweden and the UK seem to indicate that strengthening competition more forcefully can be a promising way to boost rail transport. New market entrants have helped improve performance of rail transport services in the German freight and -- to a lesser degree - the short distance passenger sector in recent years. It seems desirable to reap more of these benefits in all areas of railway transport with a more consistent approach to fostering competition.

There are other indications that competition has had favourable effects where it was allowed to occur in Germany. Cost reductions for state and local governments as a result of tendering passenger railway services linked to subsidies as opposed to direct contract awards have been reported to range between 20$40 \%$ (Holzhey and Tegner, 2004) and they have been much larger in individual cases. After paying $€ 8.50$ per train kilometre on the line Munich-Passau in a contract awarded directly to DB AG, Bavaria has recently tendered this line and this time around DB AG offered a price of $€ 0.75$ per train kilometre to carry the regional passenger traffic, while committing to operating the line with newer railcars. ${ }^{12}$ While this offer is unlikely to cover costs and an incumbent resorting to cross-subsidisation in a not fully competitive market dependent on subsidies involves problems of its own, the example testifies nevertheless to the potential of competition to reduce prices and enhance the quality of service provision in this market. More generally, the quality of transport is reported to have improved on tendered lines (Brenck and Peter, 2007) and the number of passengers has increased substantially (Leister, 2004).

\section{Political decisions on vertical separation will be crucial for the development of competition in railways}

It seems important for the government to ensure that the design of DB AG's privatisation allows competition to thrive thereafter. Experience in other countries and in other network industries suggests that a strong separation between the provision of access to the network and other essential facilities will be an important prerequisite. Germany fulfils EU unbundling requirements, but has chosen a rather weak form to do so. Currently the network operator is separate on a legal, accounting and organisational basis within DB AG's holding company. However, operational and managerial separation is limited, as managers of the holding company can and do combine executive board membership at DB AG's network or transport subsidiaries (for details see Stear Davies Gleave, 2006). Moreover, the network subsidiary shares some key staff with other parts of the holding company. A court has recently confirmed a decision by the regulator responsible for unbundling in the railway sector, the Federal Railway Office (Eisenbahnbundesamt), that had prohibited DB AG's network subsidiary from buying legal services from its holding company on matters that are crucial for network access provision. The network subsidiary is not allowed to release data on the calculations of tariffs or on its accounts without approval of the holding company, hence limiting its operational independence. 
Figure 2. Railway activity in selected countries

Freight transport performance

Index based on ton kilometres, $1995=100$

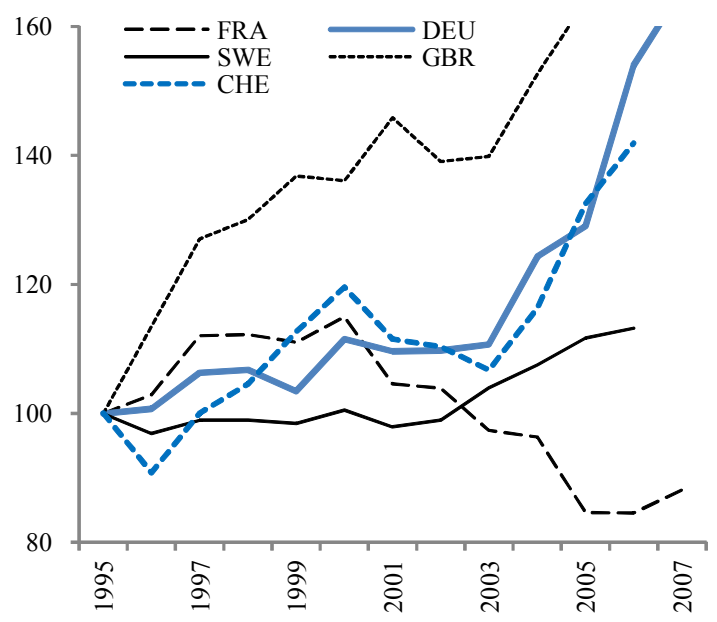

Modal split freight

Rail as \% of total land transport, ton kilometres

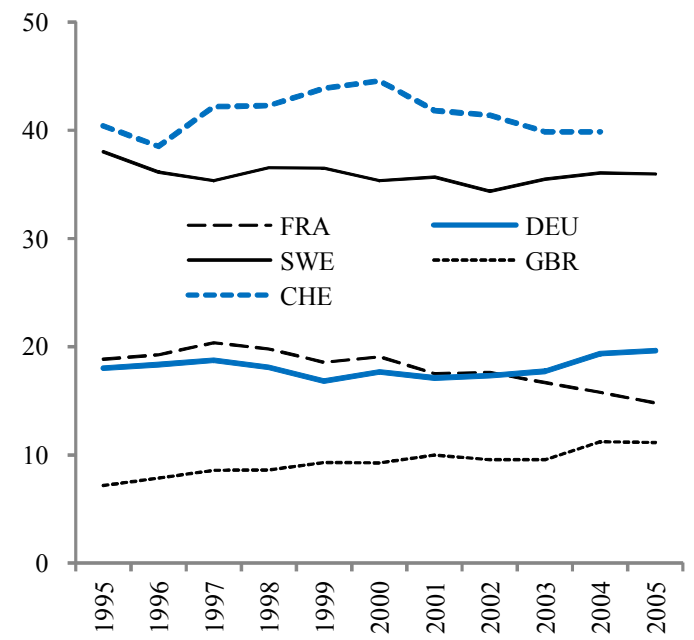

Passenger transport performance

Index based on passenger kilometres 1995, $=100$

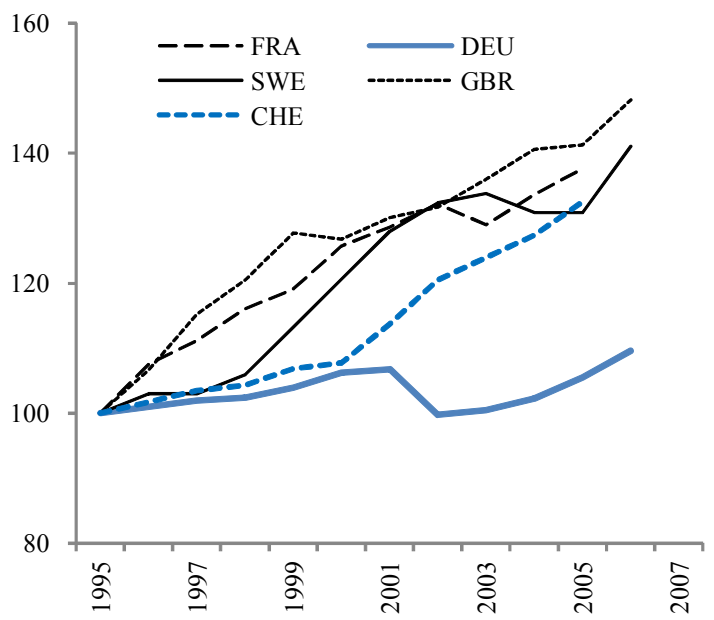

Modal split passengers

Rail as \% of total land transport, passenger kilometres

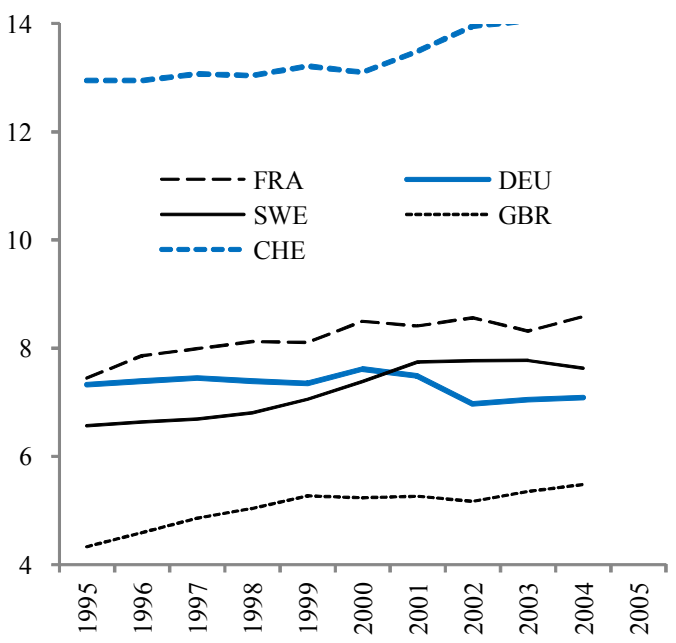

Note: Estimates for 2007. Land transport is rail, road, inland waterways and pipelines for freight and rail; passenger cars, buses and coaches and tram and metro for people.

Source: European Commission, Energy and Transport in Figures 2006 and OECD International Transport Forum, Short-term Trends Survey.

Conflicts between the incumbent and its competitors regarding conditions and charges for access to the network and other essential facilities arise in various forms. Most recently a court overruled track charges that were $10 \%$ higher for DB AG's competitors than for its affiliates. Courts are currently looking into an incident where DB AG removed gatekeepers from a line where only a competitor provides services. The regulator, FNA, responsible for fair network access is also investigating whether DB AG's station charges are discriminatory. Competitors have complained about limited access to facilities, overly high prices of traction power, non-transparent standards for the calculation of track access charges, with inadequate information both about their size and about the conditions of the tracks. ${ }^{13}$ 
It is also important to note that it does not even take actual discrimination to forestall competition; DB AG's potential to discriminate against competitors thanks to its power over essential infrastructure may often be sufficient to prevent competitors from entering the market. Operating a line as a newcomer entails substantial investments, including in trains. If competitors cannot be confident in being able to obtain fair access to the network and other essential facilities, they may easily be deterred from entering the market.

Since DB AG is still state-owned, the government is in a much better position to go for full ownership unbundling than in the energy sector and this opportunity should not be missed. An important argument against privatisation of the integrated company is that this would be very difficult to reverse as experience in the energy sector has shown. Conversely, vertically integrating infrastructure operators with DB AG later, if this were to prove desirable, would be easier and less costly. Since the experience of other countries suggests that privatisation of network industries is a learning-by-doing process, it would be preferable to choose a reform option which entails lower costs if decisions have to be corrected in the future.

Retaining full state ownership of the tracks would also help the government to disentangle its conflicting roles as a shareholder of DB AG, provider of state subsidies for investments in tracks, regulator and buyer of transport services. If the state retains full ownership of the tracks, including operation and maintenance, this would allow $100 \%$ privatisation of transport services. ${ }^{14}$ Yet, as long as the state remains a shareholder of DB AG's transport service subsidiaries with an implied interest in their profits, numerous conflicts arise with the state's sovereign tasks in the railway sector:

- Conflicts with universal service provision: There is a constitutional obligation and the political will for the state to provide railway infrastructure and services in line with public welfare considerations, implying in many cases maintenance of infrastructure and services that are not profitable. While the public interest would be to maintain this infrastructure or services at the lowest possible cost to the taxpayer, DB AG's shareholders have an interest to shut down unprofitable infrastructure or reduce unprofitable services to a minimum, while obtaining subsidies that are as high as possible. Subordinating the business interest of the integrated company to political interests would imply a risk for the company that would reduce its value on the market when it is sold. On the other hand, trying to reduce the political risk for the company by committing today to the exact amount of subsidies ${ }^{15}$ is not a good solution for at least two reasons: first, future political decision cannot and should not be limited by such an agreement. Second, experience in other countries has shown that where private companies and the government invest and do business jointly, the government often ends up bearing the largest part of the risk. ${ }^{16}$ In a similar vein, committing subsidies to a company that owns and operates the tracks can lead to strategic behaviour, whereby the company tries to gain additional public money at a later stage by claiming unexpected additional costs. Such a strategy is likely to be successful, especially if the alternative would be speed restrictions or additional punctuality problems because of a poor state of tracks or problems with signalling or electric power provision.

- Conflicts with the sovereign role as a regulator: As long as the government has an interest in DB AG's profits as its shareholder, there is an inherent temptation to influence network access regulation and prices so as to favour the transport subsidiaries of the incumbent. On the other hand, as the owner of the tracks the state would still have an interest to charge monopoly prices for network access to reduce infrastructure subsidies. This conflicts with the objective of setting access charges closer to marginal costs in the interest of competition and allocative efficiency. While this conflict cannot be avoided, it can be made transparent by defining the degree of cost coverage that is pursued with network access charges. 
- Conflicts with other business interests of DB AG: If DB AG owns and operates the tracks it has an incentive to gain unfair advantages in public tenders or gain contract awards directly by linking its offer with services related to its power over the network assets, including investment decisions, electrification, dismantling and maintenance of tracks or the modification and maintenance of railway stations. ${ }^{17}$ This is all the more a problem because infrastructure investments are financed with public money and should not be used to increase state expenditures to pay for transport services on unprofitable lines. Vertical separation of the company would reduce this risk. In addition, DB AG currently pursues a strategy of international expansion. As long as DB AG receives subsidies, there is a danger that public resources are in part diverted from infrastructure investments or from transport service provision to pursue this business strategy with questionable value to the German taxpayer.

All of these conflicts can be resolved by disentangling track ownership and operation from transport service provision, while fully selling state stakes in the transport service companies. In addition, the government should make sure that the provision of state subsidies for unprofitable services is always subject to a competitive tender process to avoid scope for the recipient to divert these funds for other purposes.

\section{Regulatory oversight needs to be made more effective}

With most of the privatisation models considered in recent times, network ownership and operation would not be fully disentangled from transport service provision. Therefore, there remains a risk that incentives and opportunities for the network operator to discriminate against DB AG's competitors will persist and in that case the regulator may need to be strengthened considerably in terms of staffing levels and competencies to allow it to perform its tasks effectively.

Irrespective of the privatisation model chosen, there are remaining institutional weaknesses that need to be addressed to make sector regulation more effective. First, it would be desirable to integrate regulation of competition in the railway sector. Currently the Federal Railway Office oversees the implementation of unbundling provisions and line closures and downgrading to low-speed tracks, actions which can be used as a form of non-price discrimination of competitors. FNA then regulates network access provisions. There is a risk that charging different regulators with tasks that ultimately have the same goal, namely ensuring fair network access and a strong framework for competition in transport services, could reduce the effectiveness of regulation. FNA should take responsibility for both. 2007c):

Other areas where the FNA's competencies need to be strengthened are (Monopolkommission,

- To avoid that DB AG transfers tasks related to infrastructure access to non-infrastructure subsidiaries, which could contest regulatory intervention, the powers for the regulator to intervene against discriminatory behaviour will have to be extended to all parts of companies that are affiliated with infrastructure operators, as opposed to being limited to infrastructure subsidiaries.

- The regulator will need access to all planning parameters including infrastructure data and electronic path planning programmes to resolve path conflicts effectively.

- The regulator will also need stronger powers to apply sanctions in case the network operator does not provide data to the regulator in line with legal requirements. 
- The regulators' possibilities to take action against discriminatory provision of transport service providers with traction energy are currently not sufficient and this legal loophole will need to be closed, as traction energy is part of the essential facilities. Energy can reach up to $20 \%$ of total costs in railway transport.

Traditionally, DB AG has been the only transport service company with guaranteed access to taxfinanced rolling stock. A second-hand leasing market for rolling stock is gradually evolving, so that lack of access to DB AG's rolling stock becomes less of barrier to entry for many competitors. Some Länder have created equal conditions for all contenders by providing the winner of transport service tenders with the necessary rolling stock. Nevertheless, it is in the interest of the taxpayer to avoid destruction or withholding of rolling stock that can still be used to provide transport services. The government should consider requiring DB AG to provide its surplus rolling stock on fair conditions to competitors.

\section{Tendering subsidised services should become the norm}

Competition in commuting passenger services should be strengthened going forward. Since commuting passenger services are in general not profitable with socially acceptable prices, competition in this market segment rests largely on public tendering of monopoly services linked to subsidies for set volumes and prices. However, the share of services tendered was below 20\% in 2004 (Tegner, 2004) and it has increased only gradually since. Given the considerable savings that have been reaped by those Länder that have resorted to tendering, more would be desirable.

Against this backdrop, there is a case for making it mandatory to tender transport service contracts that are linked with public subsidies. During the 2002-04 period most Länder have awarded large-scale long-term contracts directly to DB AG, sometimes over 10 to 12 years, and these were mainly the more profitable lines, while less lucrative services have been tendered first. Following an infringement procedure launched by the European Commission, which considered the practice of contract awarding by some Länder to amount to a violation of the EU treaties, the Länder transport ministers have committed in 2006 to choosing non-discriminatory ways of awarding contracts, which need not be in line with EU tender laws according to the agreement.

Direct contract awards to the market incumbent could partly be related to weaknesses in regulation, but there are ways to address these. The Länder buy commuting passenger services with so-called "regionalisation funds" that they receive from the federal government. In awarding these funds, little attention has been paid to build in inherent incentives for the Länder to try and save resources. Instead, they would probably have to fear cuts to their regionalisation funds in the following funding period if they did not use them fully. Recent cuts in regionalisation funds have already gone some way to increasing the need for the Länder to tap unexploited savings potential. Adding positive incentives to this, it may be worth considering giving the Länder some guarantees that funds would not be cut back by the full amount of additional savings should they occur.

In long-distance rail passenger services competition is virtually non-existent and barriers to entry are significant. Yet, competition could be built into this market segment if competitive tendering processes were introduced. Subsidies are granted only in a few cases and tendering processes are currently not applied in long-distance passenger travel, based on the assumption that this market segment is not lossmaking (eigenwirtschaftlich). However, there has been no investigation of whether this is actually the case on all lines and there is not sufficient transparency to judge whether or not DB AG's long-distance subsidiary makes use of cross-subsidies (ECORYS, 2006). The fact that some Länder, e.g. Brandenburg, open long-distance lines to commuter passenger tariffs for which operators receive subsidies in nontransparent ways suggests that the distinction between unprofitable commuter passenger travel on the one hand and supposedly profitable long distance services on the other is somewhat artificial. It would help if 
public financing of railway services would be made more transparent to have a clearer view of which lines depend on public subsidies. Public funds are provided by many different levels of government and there is currently no systematic reporting on it. In order to assess the effects of public spending on railways, the federal state and the Länder should start publishing a regular review. It would be desirable to identify and tender unprofitable long-distance lines linked to the necessary subsidies to make the process more transparent and reduce public expenditures to the necessary degree. ${ }^{18}$

\section{There is scope for more intermodal competition from buses}

In addition, allowing intermodal competition by opening the intercity bus sector may help reduce Xinefficiencies in the rail sector serving the same routes and may thus be a complementary way to reap some of the benefits of competition in long-distance passenger services. While deregulation of the intercity bus market has led to price declines of up to $40 \%$ in the United Kingdom (Monopolkommission, 2007c; Maertens, 2005), Germany has forgone these potentially beneficial effects as current regulations have effectively prevented intercity bus lines from emerging. Currently, these are limited to services to and from Berlin, which enjoys a special status for historical reasons. A license for intercity bus services can be denied on the grounds of an impingement of "public transport interests", a lack of a significant improvement of public transport or the readiness of market incumbents or the railway transport service providers to offer the same services. Even if a license were to be granted, prices for intercity bus services are subject to regulation. Restrictions on intercity bus services should be limited to what is needed for passenger safety and any possibility to block market entry by incumbent interests should be eliminated.

\section{Box 2. Recommendations to enhance competition in network industries}

\section{Energy}

- Be sure to intervene against abuses of market power, but consider carefully whether special provisions for the energy sector in the amendment of the Gesetz gegen Wettbewerbsbeschränkungen entail a risk of undermining price competition.

- Strengthen market integration with neighbouring countries, in particular by requiring revenues from auctioned interconnection capacity to be invested in interconnection capacity extension and by continuing to improve capacity management. It may be worth considering giving the regulator the power to order investment in capacity if necessary, as long as the market structure remains as concentrated as it currently is.

- $\quad$ Exploit untapped potential to encourage market entry of newcomers, including by speeding up authorisation processes for new power plants and Liquefied Natural Gas (LNG) terminals. Consider providing for privileged market access for newcomers only.

- $\quad$ Consider requiring market dominant companies to release gas, while requiring them to provide transport capacity along with it.

- Consider a stronger separation of transmission system operation and potentially competitive services, including full ownership unbundling or the establishment of independent transmission system operators. At a minimum, implement existing unbundling requirements swiftly and carefully. In that case, review whether current legal requirements for unbundling need to be strengthened, e.g. by prohibiting network operators to share staff with a holding that is affiliated with wholesalers and retailers.

- Merge market areas across networks of different owners to enhance the independence of transmission system operation and to establish a workable market access model in the gas sector. Consider price controls in the electricity balancing market, until the problem of excessive concentration in generation is resolved. 
- Make sure that mandatory minimum transparency standards in both the electricity and gas sectors cover all the necessary information and that they are enforced, while requiring verification of the data by an independent third party.

- $\quad$ Carefully review whether current laws as well as staffing levels and powers of the regulator are sufficient to enforce effective unbundling. Reconsider escape clauses and centralise regulation.

\section{Railways}

- $\quad$ Retain full state ownership of the tracks for the time being, while fully privatising DB AG's transport service subsidiaries.

- Make tendering of regional rail service contracts compulsory.

- Review overlapping regulation responsibilities of FNA and FRA and centralise regulation where appropriate. Make sure that the regulator has enough responsibilities, resources and powers to perform its task effectively, especially as long as DB AG is not fully unbundled. In particular, the regulator's competencies to oversee fair access to essential facilities will have to be extended to traction energy. The regulator will need access to all planning parameters, including electronic path planning programmes to resolve path planning conflicts and competencies to intervene will have to be extended to all parts of companies that operate network infrastructure. The regulator needs competencies to apply sanctions if the incumbent does not provide the necessary data.

- $\quad$ Open access to subsidized funding of rolling stock to all suppliers of railway transport services.

- If the Länder reap surpluses with their regionalisation funds, make sure they do not risk a 1-to-1 cut back in the subsequent funding period.

- In order to assess the effects of public spending on railways, the federal state and the Länder should start publishing a regular review, including to identify and tender unprofitable long-distance lines linked to the subsidies to make the process more transparent and reduce public expenditures to the necessary degree.

- $\quad$ Restrictions on intercity bus services should be limited to what is needed for passenger safety and any possibility to block market entry by incumbent interests should be eliminated.

1. However, the possibility to choose suppliers hardly existed since barriers to changing suppliers were high, at least initially.

2. Regarding the alternative for the FCO to effectively cap profits by overruling prices that unduly exceed costs, this might turn out to be a very difficult. There is a fine line between prices that exceed costs to a degree that this would amount to an abuse of market power and prices that exceed marginal costs sufficiently so that investment incentives remain in place in peaking generation units. In a way, a competitive price would be equal to the marginal cost of capacity rather than the marginal cost of energy and this may be difficult to identify for the regulator. This is another argument for treating the root causes of weak competition rather than the symptoms.

3. Specifically, this decree comprises a capacity right guarantee for ten years for investors who have filed for connection before the end of 2007.

4. Economies of scope and stronger investment incentives are sometimes brought forward in favour of vertical integration, but there are arguments against this. Experience suggests that liquid and competitive 
markets allow for responsive and dynamic interaction between market players. These benefits may well weigh out costs related to a reduction in economies of scope and scale as a result of vertical disintegration. As for investment incentives, market mechanisms are available providing efficient signals to the network operator how much investment in the transmission network would be profitable. This includes open season periods, whereby an infrastructure builder obtains financial commitments by selling capacity to multiple parties in a fair and open process before construction commences.

5. See Engel (2007) on the question whether interventions into property rights motivated by competition concerns are in line with the German constitution.

6. To be sure, it can be desirable to segment the market of a country into different market areas, as this can provide for efficient local market signals. The problem in Germany is that market segmentation is more often than not delineated around network property lines and mainly as a result of this it is not neutral for competition. Instead, it provides additional possibilities for large vertically integrated companies to discriminate against competitors.

7. Balancing supply and demand in a market area is necessary because electricity cannot be stored, while possibilities to store gas are limited and for technical reasons there needs to be a minimum voltage (electricity) or pressure (gas) in the network.

8. Transmission system operators charge clearing prices to network users for their services that consist in balancing aggregate demand-supply imbalances in the system. In the gas market, they also charge penalties for network users that are in imbalance individually to discourage them from taking such positions. As long as these charges are in line with the costs of providing balancing energy, there is no problem with this, but there are strong indications that this is not the case in Germany.

Originally, the voluntary cooperation agreement among market players, that established the market access models, contained an alternative, the single booking option, that was even more cumbersome than the entry-exit model. It required network users to book entry and exit capacity for each network of a different owner through which they wished to transport gas. This option was overruled by the FNA and since the gas year 2007/2008 network access can only be provided based on the entry-exit model. The entry-exit model makes gas transport a bit easier for shippers as it requires only one entry and one exit contract for each market area through which gas is transported, even if the area contains networks of different owners. Nevertheless, as long as the German market remains as segmented as it currently is, gas transport requires cumbersome parallel negotiation processes for entry and exit capacity once shippers need to transport gas through several market areas.

10 The single booking option, see footnote 9 .

11. More than $80 \%$ of technical capacity had been reviewed to arrive at this figure.

12. See Financial Times Deutschland, 2 September 2007, "Personenverkehr der Bahn stagniert".

13. See press release, mofair, 20 August 2007, "Beim Schienennetz fehlt weiterhin Transparenz".

14 If DB AG was to be privatised as a vertically integrated company that operates the tracks, current constitutional law obliges the government to keep a majority of the shares of the integrated company.

15. This had been considered by the government.

16. This lesson can be drawn from experiences with Public-Private-Partnerships (for an example see Kain, 2002).

17. There have been reports that this has happened in Germany in the past, although there is no hard evidence (Stear Davis Gleans, 2006). 


\section{ECO/WKP(2008)30}

18. Standards for transparent reporting on railway undertakings are defined in European Conference of Ministers of Transport (2007). 


\section{BIBLIOGRAPHY}

Brenck, A. and B. Peter (2007), "Experiences with Competitive Tendering in Germany", in European Conference of Transport Ministers (eds.): Competitive Tendering of Railway Services, OECD, Paris.

Bundesnetzagentur (2007), Monitoringbericht der Bundesnetzagentur für Elektrizität, Gas, Telekommunikation, Post und Eisenbahnen, Bonn.

EC (2005), Report on Progress in creating the internal Gas and Electricity Market, Technical Annex, Communication from the Commission to the Council and the European Parliament, $\operatorname{COM(2005)568}$ final, Brussels.

EC (2006), Prospects for the internal gas and electricity market - Implementation report, Accompanying document to the Communication from the Commission to the Council and the European Parliament; $\operatorname{COM}(2006) 841$ final, Brussels.

EC (2007), DG Competition Report on Energy Sector Inquiry, SEC(2006)1724, Brussels.

ECORYS (2006), Analysis of the Financial Situation of Railway Undertakings in the European Union, Report prepared for the European Commission DG-Tren, Brussels.

Engel, Ch. (2007), "Giving the German Cartel Office the Power of Divestiture - The Conformity of the Reform with Constitutional Law", Max Planck Institute for Research on Collective Goods Reprint Paper 2007/22.

European Conference of Ministers of Transport (2007), Railway Accounts for Effective Regulation, Paris.

Hirschhausen, C. et al. (2007a), Preisbildung und Marktmacht auf den Elektrizitätsmärkten in Deutschland - Grundlegende Mechanismen und empirische Evidenz, Report prepared for Verband der industriellen Energie- und Kraftwirtschaft WP-EM-15, Dresden.

Hirschhausen, C. et al. (2007b), "Competition in Natural Gas Transportation? Technical and Economical Fundamentals and an Application to Germany", Globalisation of Natural Gas Markets Working Paper, WGG-21-b, Technische Universität Dresden.

Holzhey, M. and H. Tegner (2004): Wettbewerb im Schienenverkehr. Kaum gewonnen, schon zerronnen?, Report prepared for Mehrbahnen, Berlin.

IEA (2007), Energy Policies for IEA Countries: Germany 2007 Review, IEA, Paris.

$\mathrm{KCW}$ et al. (2005), Privatisierung der integrierten DB AG - Auswirkungen und Alternativen, Report prepared for Bundesverband der Deutschen Industrie und Deutscher Industrie- und Handelstag.

Kain, P. (2002), "Attracting Private Finance for Infrastructure Projects: Lessons from the Channel Tunnel Raillink", International Volume of Transport economics, Vol. 19, No. 2, pp. 43-62. 
Lang, C. and H.-G. Schwarz (2007), "Analyse von Fly Ups am Spotmarkt der EEX 2005-2006”, IWE Working Paper No 1, Nürnberg.

Leister, H. (2004), "Mit neuen Ansätzen im Personenverkehr erfolgreich", in: Verband Deutscher Verkehrsunternehmen (ed.): Schienenpersonennahverkehr - Vom Stiefkind zur Basis nachhaltiger Mobilität, Düsseldorf.

London Economics (2007), Structure and Performance of Six European Wholesale Electricity Markets in 2003, 2004 and 2005, Report prepared for the European Commission, DG Competition.

Maertens, S. (2006), "Chancen einer Deregulierung des Intercity-Busverkehrs aus betriebs- und volkswirtschaftlicher Sicht", in: BuslinienFERNverkehr in Deutschland: Tabu oder Wettbewerbsbelebung? Schriftenreihe der deutschen verkehrswissenschaftlichen Gesellschaft, Vol. 289.

Monopolkommission (2007a), Preiskontrollen in Energiewirtschaft und Handel? Zur Novellierung des GWB, Bonn.

Monopolkommission (2007b), Strom und Gas 2007: Wettbewerbsdefizite und zögerliche Regulierung, Bonn.

Monopolkommission (2007c), Wettbewerbs- und Regulierungsversuche in der Bahn, Bonn.

Müsgens, F., "Quantifying Market Power in the German Wholesale Electricity Market Using a Dynamic Multi-Regional Dispatch Model”, The Journal of Industrial Economics, Vol. 54, pp. 471-498.

OECD (2006), OECD Economic Surveys: Germany, OECD, Paris.

Stear Davies Gleave (2006), Railimplement - Implementation of EU Directives 2001/12/EC, 2002/13/EC and 2001/14/EC, Report prepared for the European Commission - DG Energy and Transport Rail Transport and Interoperability Unit, Brussels.

Tegner, H. (2004), Marktzugang im Schienenpersonennahverkehr - Eine politökonomische Analyse, Wirtschaftsdienst No. 12, pp. 773-778. 
ECO/WKP(2008)30

\section{WORKING PAPERS}

The full series of Economics Department Working Papers can be consulted at www.oecd.org/eco/Working_Papers/

621. The Usefulness of Output Gaps for Policy Analysis

(July 2008) Isabell Koske and Nigel Pain

620. Taxation and Economic Growth

(July 2008) Åsa Johansson, Christopher Heady, Jens Arnold, Bert Brys and Laura Vartia

619. Coping with labour shortages: How to bring outsiders back to the labour market

(July 2008) Ekkehard Ernst

618. Achieving sustainability of the energy sector in Canada

(June 2008) Annabelle Mourougane

617. The Dutch tax-benefit system and life-cycle employment. Outcomes and reform options (June 2008) Ekkehard Ernst and Timo Teuber

616. Regulation, Allocative Efficiency and Productivity in OECD Countries: Industry and Firm-Level Evidence

(May 2008) Jens Arnold, Giuseppe. Nicoletti, and Stefano Scarpetta

615. Public social spending in Korea in the context of rapid population ageing

(May 2008) Randall S. Jones

614. Enhancing the globalisation of Korea

(May 2008) Randall S. Jones and Taesik Yoon

613. Reforming housing and regional policies in Korea

(May 2008) Randall S. Jones and Tadashi Yokoyama

612. Moving towards more sustainable healthcare financing in Germany

(May 2008) N. Brandt

611. Improving education outcomes in Germany

(May 2008) David Carey

610. Have developed countries escaped the curse of distance?

(May 2008) Hervé Boulhol and Alain de Serres

609. Measures of international transport cost for OECD countries

(April 2008) Stephen S. Golub and Brian Tomasik

608. Encouraging labour force participation in Chile

(April 2008) D. Contreras, L. de Mello and E. Puentes

607. Tackling business and labour informality in Chile

(April 2008) D. Contreras, L. de Mello and E. Puentes 
606. Delivery cost-efficient public services in health care, education and housing in Chile (April 2008) D. Contreras, L. de Mello and E. Puentes

605. Managing Chile's macroeconomy during and after the copper price boom (April 2008) Luiz de Mello

604. Avoiding the value added tax: Theory and cross-country evidence (April 2008) Luiz de Mello

603. Oil Price Shocks, Rigidities and the Conduct of Monetary Policy: Some Lessons from a New Keynesian Perspective (April 2008) Romain Duval and Lukas Vogel

602. The Contribution of Economic Geography to GDP Per Capita (April 2008) Hervé Boulhol, Alain de Serres and Margit Molnar

601. Estimating a supply block for Poland (April 2008) Rafal Kierzenkowski, Patric Ollivaud, Franck Sédillot and Philippe Briard

600. Product market regulation and economic performance across Indian states (March 2008) Paul Conway, Richard Herd and Thomas Chalaux

599. Improving product market regulation in India: an international and cross-state comparison (March 2008) Paul Conway and Richard Herd

598. Revenue buoyancy and its fiscal policy implications (February 2008) Isabelle Joumard and Christophe André

597. Monetary policy, market excesses and financial turmoil (February 2008) Rudiger Ahrend, Boris Cournède and Robert Price

596. Explaining differences in hours worked among OECD countries: an empirical analysis (February 2008) Sven Blondal and Jean-Marc Burniaux

595. Fiscal policy in India: past reforms and future challenges (February 2008) Richard Herd and Willi Leibfritz

594. The significance of Switzerland's enormous current-account surplus (March 2008) Peter Jarrett and Céline Letremy

593. Interdependencies between monetary policy and foreign-exchange intervention under inflation targeting: the case of Brazil and the Czech Republic

(January 2008) Jean-Yves Gnabo, Luiz de Mello and Diego Moccero

592. Solow or Lucas? Testing growth models using panel data from OECD countries (December 2007) Jens Arnold, Andrea Bassanini and Stefano Scarpetta

591. The private internal rates of return to tertiary education: new estimates for 21 OECD countries (December 2007) Romina Boarini and Hubert Strauss. 